\title{
Pengetahuan, Sikap dan Perilaku Ibu Rumah Tangga Terhadap Pengelolaan Sampah \\ di Wilayah Sekitar Rel Kereta Api, Kelurahan Jombang, Kecamatan Ciputat, Kota Tangerang Selatan
}

\author{
${ }^{1}$ Triana Srisantyorini, ${ }^{2}$ Febriana Kusuma Ningtyas \\ Program Studi Kesehatan Masyarakat, Fakultas Kesehatan Masyarakat, Universitas Muhammadiyah Jakarta \\ Jl. K.H. Ahmad Dahlan, Cirendeu, Ciputat, Tangerang Selatan 15411 \\ Email : trianasrisantyorini@yahoo.co.id
}

\begin{abstract}
ABSTRAK
Masalah sampah menjadi masalah lingkungan yang mendapat perhatian khusus dari berbagai pihak. Hal ini dikarenakan jumlah timbunan sampah terus meningkat. Jumlah peningkatan timbunan sampah di Indonesia pada tahun 2015 telah mencapai 175.000 ton/hari atau setara 64 juta ton/tahun. Tujuan penelitian ini ingin mengetahui pengetahuan, sikap dan perilaku ibu rumah tangga terhadap pengelolaan sampah di wilayah sekitar rel kereta api Kelurahan Jombang Kecamatan Ciputat Kota Tangerang Selatan. Penelitian ini bersifat kuantitatif dengan desain studi cross sectional. Sampel penelitian sebanyak 82 orang. Teknik pengambilan sampel menggunakan Simple Random Sampling. Pengumpulan data dengan cara angket menggunakan kuesioner Analisis data dilakukan dengan uji univariat untuk mengetahui gambaran dan uji chi-square untuk mengetahui hubungan variabel independen dengan variabel dependen (Convidence Interval 95\%) $(p=0,05)$. Hasil penelitian menunjukan responden memiliki pengetahuan pengelolaan sampah baik $(62,2 \%)$, sikap positif responden tentang pengelolaan sampah $(61,0 \%)$, dan perilaku responden dalam pengelolaan sampah baik $(53,4 \%)$. Variabel yang berhubungan terhadap perilaku pengelolaan sampah yaitu pendapatan (pvalue $=0,024)$, sikap (pvalue $=0,024)$, dan dukungan peraturan (pvalue $=0,049)$, sedangkan variabel yang tidak berhubungan terhadap perilaku pengelolaan sampah yaitu umur $($ vvalue $=0,901)$, pendidikan (pvalue $=0,662)$, pengetahuan (pvalue $=0,974)$, sumber informasi ( pvalue $=1,000)$, dan fasilitas tempat pembuangan sampah sementara (pvalue $=1,000)$.
\end{abstract}

Kata Kunci

: Pengetahuan, Sikap, Perilaku, Pengelolaan Sampah

\begin{abstract}
Waste problem becomes environmental problem that received special attention from various parties. This is because the number of garbage piles continues to increase. The amount of landfill increase in Indonesia in 2015 has reached 175,000 tons per day, equivalent to 64 million tons per year.. This Research aimed to know the relationship between knowledge, attitude and behavior of housewife with waste management in around railway line's area of Jombang Urban Subdistrict of Ciputat Town of South Tangerang. Type of quantitative research with cross sectional study design. The population in the study were housewives as many as 421 people, with a sample of 82 people. The sampling technique using Simple Random Sampling. Data collection by questionnaires that made by the researcher and have tested the validity and reliability test. Data analysis was done by univariate test to know the description and chi-square test to know the relation of independent variable with dependent variable (Convidence Interval 95\%) $(\mathrm{p}=0,05)$. The results showed that respondents had knowledge of good waste management (62.2\%), respondents positive attitudes about waste management $(61.0 \%)$, and respondents' behavior in good waste management $(53.4 \%)$. Variables related to waste management behavior are income $(\mathrm{p}$ value $=0.024)$, attitude $(\mathrm{p}$ value $=0.024)$, and regulatory support ( $\mathrm{p}$ value $=$ $0.049)$, while variables that are not related to waste management behavior are age ( $\mathrm{p}$ value $=0.901)$, education ( $p$ value $=0.662)$, knowledge $(p$ value $=0.974)$, source of information $(p$ value $=1,000)$, and temporary waste disposal facility $(\mathrm{p}$ value $=1,000)$.
\end{abstract}




\section{Pendahuluan}

Masalah sampah menjadi masalah lingkungan yang mendapat perhatian khusus dari berbagai pihak. Hal tersebut dikarenakan jumlah timbulan sampah terus meningkat seiring dengan meningkatnya jumlah penduduk. ${ }^{1}$

Jambeck, 2015 mengungkapkan bahwa menurut data internasional, Indonesia menempati posisi kedua penyumbang sampah terbesar di dunia hingga 187,2 juta ton, setelah negara Cina. Sedangkan Cina mencapai 262,9 juta ton. Negara tetangga seperti Filipina berada di posisi tiga dengan produksi sampah ke laut sebesar 83,4 ton. ${ }^{2}$

Pada tahun 2015 jumlah peningkatan timbulan sampah di Indonesia telah mencapai 175.000 ton/hari atau setara 64 juta ton/tahun. ${ }^{3}$ Berdasarkan hasil studi yang dilakukan di beberapa kota di Indonesia tahun 2012, pola pengelolaan sampah di Indonesia yaitu diangkut dan ditimbun di TPA (69\%), dikubur (10\%), dibuat kompos dan didaur ulang (7\%), dibakar (5\%), dan sisanya tidak terkelola $(7 \%) .{ }^{4}$

Penelitian Krisnawati, 2012 menyatakan bahwa sampah yang dihasilkan mempunyai dampak bagi semua aspek kehidupan. Dampak dari adanya sampah dapat mengganggu kesehatan. Sampah yang ditempatkan di suatu kawasan atau tempat yang tidak memadai dapat dijadikan tempat berkembangnya organisme pembawa penyakit (vektor penyakit), seperti contoh timbulnya penyakit jamur, diare, kolera, demam berdarah. Selain itu juga dapat

menimbulkan penyakit taenia serta keracunan akibat adanya sampah B3. Selain berbahaya bagi kesehatan, ternyata sampah juga dapat menyebabkan pencemaran bagi lingkungan. ${ }^{5}$

Data DKPP Tangerang Selatan 2010 Jumlah penduduk di kota Tangerang Selatan mencapai 1.303.569 jiwa, $^{6}$ timbulan sampah per hari kota Tangerang Selatan sekitar 3.919 $\mathrm{m}^{3} /$ hari. ${ }^{7}$ Kelurahan Jombang merupakan salah satu kelurahan yang berada di wilayah Kecamatan Ciputat yang mempunyai Luas Wilayah $3.450 \mathrm{Km}^{2}$. Dimana pengelolaan dan penanganan sampah pemukiman belum teratasi secara keseluruhan. Dilihat dari banyaknya timbunan sampah di sepanjang pinggir rel kereta api Stasiun Sudimara. Bertambahnya jumlah sampah ini harus di imbangi dengan pengelolaan sampah khususnya pengelolaan yang berbasis lingkungan. Pengetahuan, sikap dan perilaku merupakan komponen penting yang dapat menunjang perilaku ibu rumah tangga terhadap pengelolaan sampah. Tujuan penelitian ini ingin mengetahui pengetahuan, sikap dan perilaku ibu rumah tangga terhadap pengelolaan sampah di wilayah sekitar rel kereta api Kelurahan Jombang Kecamatan Ciputat Kota Tangerang Selatan.

\section{Metode Penelitian}

Jenis penelitian kuantitatif dengan pendekatan desain studi Cross Sectional. Populasi penelitian ibu rumah tangga RW 09 Kelurahan Jombang yaitu sebanyak 421 orang, dengan sampel 82 orang. Teknik pengambilan sampel 
Triana Srisantyorini, Febriana Kusuma. Ningtyas Pengetahuan, Sikap dan Perilaku Ibu Rumah Tangga Terhadap Pengelolaan Sampah di Wilayah Sekitar Rel Kereta Api, Kelurahan Jombang, Kecamatan Ciputat, Kota Tangerang Selatan DOI :

menggunakan Simple Random Sampling. Pengumpulan data dilakukan dengan cara memberikan kuesioner kepada responden untuk mengisi sendiri kuesioner yang diberikan (angket). Data dalam kuesioner berisi mengenai karakteristik responden, pengetahuan, sikap, perilaku, media informasi, fasilitas tempat pembuangan sampah dan dukungan peraturan dari RT/RW. Analisis data dilakukan dengan uji univariat untuk mengetahui gambaran dan uji chi-square untuk mengetahui hubungan variabel independen dengan variabel dependen (CI 95\%) $(p=0,05)$.

\section{Hasil}

Analisis Univariat

Tabel 1

Rekapitulasi Analisis Univariat

\begin{tabular}{|c|c|c|c|c|c|}
\hline \multirow{2}{*}{ Variabel } & \multirow{2}{*}{ Kategori } & \multirow{2}{*}{$\mathbf{N}$} & \multirow{2}{*}{$\%$} & \multicolumn{2}{|c|}{ Jumlah } \\
\hline & & & & $\mathbf{N}$ & $\%$ \\
\hline \multirow{2}{*}{ Umur Responden } & Dewasa awal (20 - 30 tahun) & 28 & 34,1 & \multirow{2}{*}{82} & \multirow{2}{*}{100,0} \\
\hline & Dewasa akhir (31-60 tahun) & 54 & 65,9 & & \\
\hline Pendidikan & Tinggi (SMA - Perguruan Tinggi) & 34 & 41,5 & \multirow{2}{*}{82} & \multirow{2}{*}{100,0} \\
\hline Responden & Rendah (SD - SMP) & 48 & 58,5 & & \\
\hline Pendapatan & $>=\mathrm{UMK}$ & 18 & 22,0 & \multirow{2}{*}{82} & \multirow{2}{*}{100,0} \\
\hline Responden & $<\mathrm{UMK}$ & 64 & 78,0 & & \\
\hline Pengetahuan & Baik & 51 & 62,2 & \multirow{2}{*}{82} & \multirow{2}{*}{100,0} \\
\hline Responden & Cukup & 29 & 35,4 & & \\
\hline \multirow{2}{*}{ Sikap Responden } & Kurang & 2 & 2,4 & \multirow{3}{*}{82} & \multirow{3}{*}{100,0} \\
\hline & Positif & 50 & 61,0 & & \\
\hline \multirow{2}{*}{ Perilaku Responden } & Negatif & 32 & 39,0 & & \\
\hline & Baik & 52 & 63,4 & \multirow[t]{2}{*}{82} & \multirow[t]{2}{*}{100,0} \\
\hline Sumber Informasi & Kurang & 30 & 36,6 & & \\
\hline Responden & Terpapar & 45 & 54,9 & 82 & 100,0 \\
\hline \multirow{2}{*}{ Fasilitas TPS } & Kurang terpapar & 37 & 45,1 & \multirow{3}{*}{82} & \multirow{3}{*}{100,0} \\
\hline & Ada & 46 & 56,1 & & \\
\hline \multirow{2}{*}{ Dukungan Peraturan } & Tidak & 36 & 43,9 & & \\
\hline & Ada & 29 & 35,4 & 82 & 100,0 \\
\hline
\end{tabular}

Berdasarkan tabel 1 diketahui bahwa dari total 82 responden menurut didapatkan hasil deskripsi mengenai umur mayoritas responden berusia dewasa akhir (31 - 60 tahun) sebanyak 54 responden $(65,9 \%)$, memiliki pendidikan rendah (SD - SMP) sebanyak 48 responden (58,5\%), pendapatan rendah (< UMK) sebanyak 64 responden $(78,0 \%)$, pengetahuan baik sebanyak 51 responden $(62,2 \%)$, sikap positif sebanyak 50 responden $(61,0 \%)$, perilaku pengelolaan sampah yang baik sebanyak 52 responden (63,4\%), terpapar sumber informasi sebanyak 45 responden $(54,9 \%)$, responden yang mengatakan "ya/ ada" terhadap ketersediaan fasilitas TPS sebanyak 46 responden $(56,1 \%)$, responden mengatakan 
tidak ada dukungan peraturan dari RT/RW 53

responden $(64,6 \%)$

Analisis Bivariat

Tabel 2

Hasil Rekapitulasi Bivariat

\begin{tabular}{|c|c|c|c|c|c|c|c|c|}
\hline \multirow{3}{*}{ Variabel } & \multicolumn{4}{|c|}{$\begin{array}{c}\text { Perilaku Pengelolaan } \\
\text { Sampah }\end{array}$} & \multicolumn{2}{|c|}{ Total } & \multirow{3}{*}{$\begin{array}{c}\text { OR } \\
(95 \% \mathrm{CI})\end{array}$} & \multirow{3}{*}{$\begin{array}{c}\mathrm{P} \\
\text { Value }\end{array}$} \\
\hline & \multicolumn{2}{|c|}{ Baik } & \multicolumn{2}{|c|}{ Kurang } & \multirow[b]{2}{*}{$\mathbf{N}$} & \multirow[b]{2}{*}{$\%$} & & \\
\hline & $\mathbf{n}$ & $\%$ & $\mathbf{n}$ & $\%$ & & & & \\
\hline \multicolumn{9}{|c|}{ 1. Umur Responden } \\
\hline Dewasa awal & 17 & 60,7 & 11 & 39,3 & 28 & 100 & \multirow{2}{*}{$\begin{array}{c}0,839 \\
(0,327-2,152)\end{array}$} & \multirow{3}{*}{0,901} \\
\hline Dewasa akhir & 35 & 64,8 & 19 & 35,2 & 54 & 100 & & \\
\hline Jumlah & 52 & 63,4 & 30 & 36,6 & 82 & 100 & & \\
\hline \multicolumn{9}{|l|}{ 2. Pendidikan } \\
\hline Tinggi & 23 & 67,6 & 11 & 32,4 & 34 & 100 & \multirow{3}{*}{$\begin{array}{c}1,370 \\
(0,545-3,446)\end{array}$} & \multirow{2}{*}{0,662} \\
\hline Rendah & 29 & 60,4 & 19 & 39,6 & 48 & 100 & & \\
\hline Jumlah & 52 & 63,4 & 30 & 36,6 & 82 & 100 & & \\
\hline \multicolumn{9}{|l|}{ 3. Pendapatan } \\
\hline Tinggi $\geq U M K$ & 16 & 88,9 & 2 & 11,1 & 18 & 100 & \multirow{3}{*}{$\begin{array}{c}6,222 \\
(1,320-29,337)\end{array}$} & \multirow{2}{*}{$0,024^{*}$} \\
\hline Rendah < UMK & 36 & 56,2 & 28 & 43,8 & 64 & 100 & & \\
\hline Jumlah & 52 & 63,4 & 30 & 36,6 & 81 & 100 & & \\
\hline \multicolumn{9}{|l|}{ 4. Pengetahuan } \\
\hline Baik & 35 & 68,6 & 16 & 31,4 & 51 & 100 & & \multirow{3}{*}{0,974} \\
\hline Cukup & 16 & 55,2 & 13 & 44,8 & 29 & 100 & & \\
\hline Kurang & 1 & 50,0 & 1 & 50,0 & 2 & 100 & & \\
\hline Jumlah & 52 & 63,4 & 30 & 36,6 & 82 & 100 & & \\
\hline \multicolumn{9}{|l|}{ 5. Sikap } \\
\hline Positif & 37 & 74,0 & 13 & 26,0 & 50 & 100 & \multirow{2}{*}{$\begin{array}{c}3,226(1,262- \\
8,248)\end{array}$} & \multirow{2}{*}{$0,024 *$} \\
\hline Negatif & 15 & 46,9 & 17 & 53,1 & 32 & 100 & & \\
\hline Jumlah & 52 & 63,4 & 30 & 36,6 & 82 & 100 & & \\
\hline \multicolumn{9}{|c|}{ 6. Sumber Informasi } \\
\hline Terpapar & 29 & 64,4 & 16 & 35,6 & 45 & 100 & \multirow{3}{*}{$\begin{array}{c}1,103(0,448- \\
2,720)\end{array}$} & \multirow{3}{*}{1,000} \\
\hline Kurang Terpapar & 23 & 62,2 & 14 & 37,8 & 37 & 100 & & \\
\hline Jumlah & 52 & 63,4 & 30 & 36,6 & 82 & 100 & & \\
\hline \multicolumn{9}{|c|}{ 7. Ketersediaan Fasilitas TPS } \\
\hline Ada & 29 & 63,0 & 17 & 37,0 & 46 & 100 & $0,964(0,390-$ & 1000 \\
\hline Tidak & 23 & 63,9 & 13 & 36,1 & 36 & 100 & $2,386)$ & 1,000 \\
\hline Jumlah & 52 & 63,4 & 30 & 36,6 & 82 & 100 & & \\
\hline 8. Dukungan $P$ & & & & & & & & \\
\hline Ada & 23 & 79,3 & 6 & 20,7 & 29 & 100 & $3,172(1,112-$ & $0040 *$ \\
\hline Tidak & 29 & 54,7 & 24 & 45,3 & 53 & 100 & $9,054)$ & $0,049 \pi$ \\
\hline Jumlah & 52 & 63,4 & 30 & 36,6 & 82 & 100 & & \\
\hline
\end{tabular}

Berdasarkan Tabel 2 Hasil analisis hubungan antara umur dengan perilaku pengelolaan sampah diperoleh bahwa, ada sebanyak $17(60,7 \%)$ responden yang berada di 
Triana Srisantyorini, Febriana Kusuma. Ningtyas Pengetahuan, Sikap dan Perilaku Ibu Rumah Tangga Terhadap Pengelolaan Sampah di Wilayah Sekitar Rel Kereta Api, Kelurahan Jombang, Kecamatan Ciputat, Kota Tangerang Selatan DOI :

umur dewasa awal melakukan perilaku pengelolaan sampah secara baik, lebih sedikit dibandingkan dengan responden yang berada di umur dewasa akhir ada sebanyak $35(64,8 \%)$ yang melakukan perilaku pengelolaan sampah secara baik. Nilai $p$-value $=0,901$ artinya tidak ada hubungan yang signifikan (bermakna) antara umur dengan perilaku pengelolaan sampah.

Hasil analisis hubungan antara pendidikan dengan perilaku pengelolaan sampah diperoleh sebanyak $23(67,6 \%)$ responden yang memiliki pendidikan tinggi melakukan perilaku pengelolaan sampah secara baik, lebih banyak dibandingkan dengan responden yang memiliki pendidikan rendah sebanyak $29(60,4 \%)$ yang melakukan perilaku pengelolaan sampah secara baik. Hasil analisis statistik diperoleh $p$-value $=$ 0,662 artinya tidak ada hubungan yang signifikan (bermakna) antara pendidikan dengan perilaku pengelolaan sampah.

Hasil analisis hubungan antara pendapatan dengan perilaku pengelolaan sampah diperoleh sebanyak $16(88,9 \%)$ responden yang memiliki pendapatan tinggi melakukan perilaku pengelolaan sampah secara baik, lebih banyak dibandingkan dengan responden yang memiliki pendapatan rendah sebanyak $36(56,2 \%)$ yang melakukan perilaku pengelolaan sampah secara baik. Hasil analisis statistik diperoleh $p$-value $=$ 0,024 artinya ada hubungan yang signifikan (bermakna) antara pendapatan dengan perilaku pengelolaan sampah. Nilai $\mathrm{OR}=6,222$ artinya ibu rumah tangga yang pendapatannya tinggi memiliki peluang melakukan perilaku pengelolaan sampah 6,222 kali dibandingkan dengan ibu rumah tangga yang memiliki pendapatan rendah.

Hasil analisis hubungan antara pengetahuan dengan perilaku pengelolaan sampah diperoleh sebanyak $35(68,6 \%)$ responden yang memiliki pengetahuan baik melakukan perilaku pengelolaan sampah secara baik, lebih banyak dibandingkan dengan responden yang memiliki pengetahuan cukup sebanyak $16(55,2 \%)$ dan responden yang memiliki pengetahuan kurang sebanyak $1(50,0 \%)$ yang melakukan perilaku pengelolaan sampah secara baik. Hasil analisis diperoleh $p$-value $=0,449$ artinya tidak ada hubungan yang signifikan (bermakna) antara pengetahuan dengan perilaku pengelolaan sampah.

Hasil analisis hubungan antara sikap dan perilaku pengelolaan sampah diperoleh, ada sebanyak $37(74,0 \%)$ responden yang memiliki sikap positif melakukan perilaku pengelolaan sampah secara baik, lebih banyak dibandingkan dengan responden yang memiliki sikap negatif ada sebanyak 15 (46,9\%) yang melakukan perilaku pengelolaan sampah secara baik. Hasil analisis statistik diperoleh pvalue $=0,024$ artinya ada hubungan yang signifikan (bermakna) antara sikap dengan perilaku pengelolaan sampah. Nilai $\mathrm{OR}=3,226$ artinya, ibu rumah tangga dengan sikap positif berpeluang 3,226 kali untuk melakukan perilaku pengelolaan sampah dibandingkan dengan ibu rumah tangga dengan sikap negatif.

Hasil analisis hubungan antara sumber informasi dengan perilaku pengelolaan sampah diperoleh bahwa, ada sebanyak 29 (64,4\%) responden yang terpapar sumber informasi 
melakukan perilaku pengelolaan sampah secara baik, lebih banyak dibandingkan dengan responden yang tidak terpapar sumber informasi sebanyak $23(62,2 \%)$ yang melakukan perilaku pengelolaan sampah secara baik. Hasil analisis statistik diperoleh $p$ value $=1,000$ artinya tidak ada hubungan yang signifikan (bermakna) antara sumber informasi dengan perilaku pengelolaan sampah.

Hasil analisis hubungan antara Fasilitas TPS dan perilaku pengelolaan sampah diperoleh, ada sebanyak $29 \quad(63,0 \%)$ responden yang menyatakan adanya ketersediaan fasilitas TPS melakukan perilaku pengelolaan sampah secara baik, lebih sedikit dibandingkan dengan responden yang menyatakan tidak adanya ketersediaan fasilitas TPS ada sebanyak 23 $(63,9 \%)$ yang melakukan perilaku pengelolaan sampah secara baik. Hasil analisis statistik diperoleh $p$ value $=1,000$ artinya tidak ada hubungan yang signifikan (bermakna) antara Fasilitas TPS dengan perilaku pengelolaan sampah.

Hasil analisis hubungan antara Fasilitas TPS dan perilaku pengelolaan sampah diperoleh, ada sebanyak $29 \quad(63,0 \%)$ responden yang menyatakan adanya ketersediaan fasilitas TPS melakukan perilaku pengelolaan sampah secara baik, lebih sedikit dibandingkan dengan responden yang menyatakan tidak adanya

Dari hasil penelitian didapatkan bawah tidak ada hubungan yang signifikan (bermakna) antara umur dengan perilaku pengelolaan sampah $(p$ value $=0,901)$. Namun demikinan dari data yang didapatkan bahwa responden dengan umur dewasa akhir memiliki ketersediaan fasilitas TPS ada sebanyak 23 $(63,9 \%)$ yang melakukan perilaku pengelolaan sampah secara baik. Hasil analisis statistik diperoleh $p$ value $=1,000$ artinya tidak ada hubungan yang signifikan (bermakna) antara Fasilitas TPS dengan perilaku pengelolaan sampah.

Hasil analisis hubungan antara dukungan peraturan dan perilaku pengelolaan sampah diperoleh, ada sebanyak 23 (79,3\%) responden yang menyatakan adanya dukungan peraturan RT/RW melakukan perilaku pengelolaan sampah secara baik, lebih banyak dibandingkan dengan responden yang menyatakan tidak ada nya dukungan peraturan RT/RW ada sebanyak $29(54,7 \%)$ yang melakukan perilaku pengelolaan sampah secara baik. Hasil analisis statistik diperoleh pvalue $=0,049$ artinya ada hubungan yang signifikan (bermakna) antara dukungan peraturan dengan perilaku pengelolaan sampah. Kemudian diperoleh pula nilai $\mathrm{OR}=3,172$ artinya, ibu rumah tangga yang menyatakan adanya dukungan peraturan berpeluang 3,172 kali untuk melakukan perilaku pengelolaan sampah dibandingkan dengan ibu rumah tangga yang menyatakan adanya dukungan peraturan mengenai pengelolaan sampah.

\section{Diskusi}

kecenderungan untuk melakukan perilaku pengelolaan sampah dibandingkan responden dengan umur dewasa muda. Penelitian ini sejalan dengan penelitian Besth, 2015 dengan hasil uji statistik $p$ value $=0,708$ sehingga dapat dinyatakan tidak ada hubungan bermakna 
Triana Srisantyorini, Febriana Kusuma. Ningtyas Pengetahuan, Sikap dan Perilaku Ibu Rumah Tangga Terhadap Pengelolaan Sampah di Wilayah Sekitar Rel Kereta Api, Kelurahan Jombang, Kecamatan Ciputat, Kota Tangerang Selatan DOI :

antara umur dengan perilaku pengelolaan sampah. $^{2}$

Meskipun hasil uji statistik tidak ada hubungan antara pendidikan dengan perilaku pengelolaan sampah namun data yang didapatkan bahwa responden dengan pendidikan tinggi memiliki kecenderungan untuk melakukan perilaku pengelolaan sampah dibandingkan responden dengan pendidikan rendah. Penelitian ini sejalan dengan penelitian Setyowati (2012), dimana tidak ada hubungan antara tingkat pendidikan dengan perilaku pengelolaan sampah padat. $^{8}$ Akan tetapi penelitian ini tidak sejalan dengan penelitian Riswan (2011) dengan hasil uji statistik $p=0,006$ yang menyatakan bahwa ada hubungan antara pendidikan dengan perilaku pengelolaan sampah. ${ }^{9}$

Hasil uji statistik terdapat hubungan antara pendapatan dengan perilaku pengelolaan sampah. Penelitian ini sejalan dengan penelitian Riswan (2011) dengan hasil uji statistik $p$ value $=0,036$ yang menyatakan bahwa ada hubungan antara pendapatan dengan perilaku pengelolaan sampah. ${ }^{9}$

Meskipun hasil uji statistik tidak ada hubungan antara pengetahuan dengan perilaku pengelolaan sampah namun data yang didapatkan bahwa responden yang pengetahuan nya baik memiliki kecenderungan untuk melakukan perilaku pengelolaan sampah dibandingkan responden dengan pengetahuan cukup dan kurang. Hasil penelitian ini sejalan dengan penelitian Fitrul (2009) dengan hasil uji statistik $p$ value $=0,129$ yang mengatakan bahwa tidak ada hubungan yang signifikan antara pengetahuan dengan perilaku pembuangan sampah. ${ }^{10}$

Hasil penelitian terdapat hubungan sikap dengan perilaku pengelolaan sampah. Hasil penelitian ini sejalan dengan penelitian Fitrul (2009) dengan hasil uji statistik $p$ value $=0,037$ yang menunjukkan ada hubungan yang signifikan antara sikap dengan perilaku pembuangan sampah. ${ }^{10}$

Berdasarkan hasil penelitian tidak ada hubungan yang signifikan antara sumber informasi dengan perilaku pengelolaan sampah. Meskipun hasil uji statistik tidak ada hubungan antara sumber informasi dengan perilaku pengelolaan sampah namun data yang didapatkan bahwa responden yang terpapar sumber informasi memiliki kecenderungan untuk melakukan perilaku pengelolaan sampah dibandingkan responden dengan yang tidak terpapar sumber informasi. Pengaruh media massa tidaklah sebesar pengaruh interaksi individual secara langsung, namun dalam proses pembentukan dan perubahan sikap, peranan media massa tidak kecil artinya. Dalam pemberitaan surat kabar maupun di radio atau media komunikasi lainnya, berita-berita faktual yang seharusnya di sampaikan secara objektif seringkali dimasuki unsur subjektifitas penulis berita, baik secara sengaja ataupun tidak (Azwar, 2011) ${ }^{11}$. Media merupakan sarana yang memiliki peran sangat besar dalam sosialisasi dan penyebaran informasi guna meningkatkan pengetahuan (Ozumba, 2007). ${ }^{12}$

Hasil penelitian tidak ada hubungan yang signifikan antara ketersediaan fasilitas TPS dengan perilaku pengelolaan sampah. 
Meskipun hasil uji statistik tidak ada hubungan antara ketersediaan fasilitas TPS dengan perilaku pengelolaan sampah namun data yang didapatkan bahwa responden yang menyatakan ada nya ketersediaan TPS memiliki kecenderungan untuk melakukan perilaku pengelolaan sampah dibandingkan responden dengan yang menyatakan tidak tersedianya TPS. Hasil penelitian ini sejalan dengan penelitian Nu'man (2015) dengan hasil uji statistik $p$ value $=0,094$ yang mengatakan bahwa tidak ada hubungan yang antara ketersediaan fasilitas dengan perilaku pengelolaan sampah rumah tangga. ${ }^{13}$

Berdasarkan hasil uji statistik ada hubungan yang signifikan (bermakna) antara dukungan peraturan dengan perilaku pengelolaan sampah. Hasil penelitian ini sejalan dengan penelitian Nu'man (2015) dengan hasil uji statistik $p$ value $=0,000$ yang mengatakan bahwa ada hubungan yang antara peran dukungan peraturan tokoh masyarakat dengan perilaku pengelolaan sampah rumah tangga. ${ }^{13}$

\section{Kesimpulan}

1. Berdasarkan hasil univariat bahwa distribusi frekuensi responden menurut perilaku pengelolaan sampah lebih banyak responden yang memiliki perilaku pengelolaan sampah baik sebanyak 52 orang $(53,4 \%)$, pengetahuan responden tentang pengelolaan sampah lebih banyak responden yang memiliki pengetahuan baik sebanyak 51 orang $(62,2 \%)$, sikap responden tentang pengelolaan sampah lebih banyak responden yang memiliki sikap positif sebanyak 50 orang $(61,0 \%)$, s

2. Kelompok umur lebih banyak responden dengan kelompok umur dewasa akhir (3160 tahun) sebanyak 54 orang $(65,9) \%$, pendidikan lebih banyak responden dengan pendidikan rendah (SD-SMP) sebanyak 48 orang $(58,5 \%)$, pendapatan lebih banyak responden dengan pendapatan rendah < UMK sebanyak 64 orang $(78,0 \%)$, sumber informasi responden lebih banyak yang terpapar sumber informasi sebanyak 45 orang $(54,9 \%)$, ketersediaan fasilitas TPS lebih banyak responden yang menunjukkan ada nya fasilitas TPS sebanyak $46(56,1 \%)$, dukungan peraturan $\mathrm{RT} / \mathrm{RW}$ responden lebih banyak yang menunjukkan tidak ada nya dukungan peraturan dari RT/RW setempat sebanyak 53 orang $(64,6 \%)$.

3. Ada hubungan yang signifikan (bermakna) antara pendapatan, sikap, dan dukungan peraturan terhadap perilaku pengelolaan sampah dengan pvalue $<0,005$.

4. Tidak ada hubungan yang signifikan (bermakna) antara umur, pendidikan, pengetahuan, sumber informasi, dan fasilitas TPS terhadap perilaku pengelolaan sampah.

\section{Daftar Pustaka}

1. JICA. 2008. Statistik Persampahan Indonesia. Kementrian Negara Lingkungan Hidup. Jakarta

2. Jambeck, 2015. Jurnal Science (www.sciencemag.org) pada 12 Februari 2015 
Triana Srisantyorini, Febriana Kusuma. Ningtyas Pengetahuan, Sikap dan Perilaku Ibu Rumah Tangga Terhadap Pengelolaan Sampah di Wilayah Sekitar Rel Kereta Api, Kelurahan Jombang, Kecamatan Ciputat, Kota Tangerang Selatan DOI :

3. KLH. 2015. Panduan Praktis Pemilahan Sampah. KLH: Jakarta

4. WWF Indonesia. 2016. Artikel : Antara Kita, Plastik, dan Lingkungan. Diakses di http://www.wwf.or.id/?44982/Antara-KitaPlastik-dan-Lingkungan pada 29 Januari 2017.

5. Krisnawati Oktarina, Theresia. 2012. Pengelolaan Sampah Domestik Masyarakat Dan Jumlah Titik Sampah di Tepi Sungai Code Wilayah Gondolayu Sampai Ringroad Utara Yogyakarta.

6. Badan Pusat Stastistik Kabupaten Tangerang. 2010.

7. Dinas Kebersihan Pertamanan dan Pemakaman. 2010. Profil Dinas Kebersihan Pertamanan dan Pemakaman Kota Tangerang Selatan.

8. Setyowati Ririn, Mulasari S.A., Pengetahuan dan Perilaku Ibu Rumah Tangga dalam Pengelolaan Sampah Plastik. National Public Health Journal, Vol 7 No. 12 Juli 2013

9. Riswan, dkk. 2011. Pengelolaan Sampah Rumah Tangga di Kecamatan Daha Selatan.
Jurnal Ilmu Lingkungan. Volume 9 No.1 diakses tanggal 14 April 2017

10.Fitrul, Kamal. 2009. Hubungan antara Tingkat Pengetahuan dan Sikap Ibu Rumah Tangga Tentang Pengelolaan Sampah dengan Perilaku Pembuangan Sampah pada Masyarakat Sekitar Sungai Beringin di RW 07 Kelurahan Wonosari Kecamatan Ngaliyan Kota Semarang Tahun 2009. Universitas Negeri Semarang

11. Azwar, S. 2011. Sikap Manusia Teori Dan Pengukurannya. Yogyakarta: Pustaka Pelajar.

12. Ozumba B. C. 2007. The impact of health education on reproductive health knowledge among adolescents in a rural Nigerian community. Melalui http://cat.inist.fr/?aModele=afficheN\&cps $\underline{\mathrm{idt}=19041320}$

13. Nu'man, Naqi Ahmad. 2015. FaktorFaktor yang Mempengaruhi Pengelolaan Sampah Rumah Rangga di Perumahan Bukit Permata Puri Kelurahan Beringin Kecamatan Ngaliyan Kota Semarang Tahun 2015. Fakultas Kesehatan Universitas Dian Nuswantoro 